\title{
Wiedza i opinie studentów na temat transplantacji narządów
}

Knowledge and students opinions on organ transplantation

\author{
MARTA KAMIŃSKA¹, KLAUDIA DASZUTA²
}

\author{
${ }^{1}$ Studenckie Koło Naukowe Nauk o Zdrowiu, Instytut Nauk o Zdrowiu PWSZ \\ we Włocławku, opiekun Koła: dr Beata Haor \\ ${ }^{2}$ Instytut Nauk o Zdrowiu Państwowej Wyższej Szkoły Zawodowej we Włocławku \\ ${ }^{3}$ koordynator pobierania i przeszczepiania narządów Wojewódzki Szpital Specjalistyczny \\ im. Bł. ks. J. Popiełuszki we Włocławku \\ DOI: http://dx.doi.org/10.21784/IwP.2019.009 \\ ISSN: 2451-1846
}

\section{Streszczenie:}

Wstęp. Transplantacja narządów, komórek i tkanek to uznana metoda leczenia pacjentów w ze schyłkową niewydolnością narządów.

Cel. Celem badań było porównanie wiedzy i opinii studentów Państwowej Wyższej Szkoły Zawodowej we Włocławku oraz respondentów Centrum Badania Opinii Społecznej (CBOS) na temat transplantacji narządów.

Materiał i metody. Badania przeprowadzono wśród 80 studentów Państwowej Wyższej Szkoły Zawodowej we Włocławku. Wykorzystano metodę sondażu diagnostycznego, technikę ankietowania oraz autorski kwestionariusz ankiety.

Wyniki. Studenci w większości deklarują gotowość oddania własnych narządów do transplantacji po swojej śmierci. Podobnie jak znaczny odsetek Polaków wykazują jednak niedostatki wiedzy na temat transplantacji narządów i regulacji prawnych.

Wnioski. Stosunek studentów PWSZ we Włocławku jak i większości Polaków wobec transplantacji narządów jest pozytywny. Istnieje potrzeba 
propagowania idei transplantologii oraz wiedzy na temat zasad przeszczepiania narządów, tkanek i komórek.

Słowa kluczowe: transplantacja, wiedza, student

\begin{abstract}
:
Introduction. Transplantation of organs, cells and tissues is a recognized method of treating patients with end-stage organ failure.

The aim. The aim of the study was to compare the knowledge and opinions of students of the State Higher Vocational School in Włocławek and respondents of the Center for Public Opinion Research (CBOS) on organ transplantation.

Material and methods. The research was conducted among 80 students of the State Higher Vocational School in Włocławek. The method of diagnostic survey, questionnaire technique and author's questionnaire was used.

Results. Most students declare their willingness to donate their organs for transplantation after their death. Similarly, a significant percentage of Poles show insufficient knowledge about organ transplantation and legal regulations.

Conclusions. The attitude of the PWSZ students in Włocławek and the majority of Poles towards organ transplants is positive. There is a need to promote the idea of transplantology and knowledge about the principles of transplantation of organs, tissues and cells.
\end{abstract}

Keywords: transplantation, knowledge, student

\title{
Wstęp
}

W ostatnich dekadach transplantologia stała się dynamicznie rozwijającą się dziedziną medycyny na świecie. W związku z tym, że często procedura transplantacji odbywa się na pograniczu śmierci dawcy oraz życia dawcy, działania te rodzą szereg dyskusji społecznych, wynikających z odrębności kulturowych i religijnych społeczeństw [1,2]. 
Transplantacja inaczej przeszczepianie narządów to metoda leczenia stosowana $\mathrm{w}$ celu ratowania życia osoby ze skrajnie niewydolną funkcją narządu. Metoda ta polega na wszczepieniu biorcy narządu lub tkanek pochodzących od dawcy. Niektóre narządy, takie jak nerki, wątroba lub tkanki - szpik kostny - można pobrać od osób żywych pod warunkiem, że dawca wyrazi na to zgodę, a jego życie nie będzie narażone na niebezpieczeństwo [3]. Większość narządów i tkanek do przeszczepienia pobiera się jednak ze zwłok osób, które za życia nie wyraziły sprzeciwu na ich pobranie po śmierci $[1,3]$.

Celem badań było porównanie wiedzy i opinii studentów Państwowej Wyższej Szkoły Zawodowej we Włocławku oraz respondentów Centrum Badania Opinii Społecznej (CBOS) na temat transplantacji narządów.

\section{Materiał i metody}

Badania przeprowadzono w 2019 roku wśród 80 studentów Państwowej Wyższej Szkoły Zawodowej we Włocławku. Wyniki zostały porównane z badaniami CBOS z 2016r. na reprezentatywnej próbie losowej 983 dorosłych mieszkańców Polski [4].

W aktualnych badaniach wykorzystano metodę sondażu diagnostycznego, technikę ankietowania oraz autorski kwestionariusz ankiety. Natomiast badanie CBOS przeprowadzono metodą wywiadów bezpośrednich (face-to-face) wspomaganych komputerowo (CAPI) [4]. 


\section{Wyniki}

W aktualnych badaniach uczestniczyło 80 studentów z kierunków: pielęgniarstwo (46,25\%), pedagogika (16,25\%), inżynieria zarządzania (17,5\%), administracja (5\%), finanse i rachunkowość $(7,5 \%)$, nowe media i e - biznes $(6,25 \%)$ i filologia angielska $(1,25 \%)$. Większość badanych stanowiły kobiety $(86,2 \%)$ oraz mieszkańcy miasta $(67,8 \%)$. Średnia wieku respondentów wynosiła 25,4. Większość ankietowanych to panny i kawalerowie (65,5\%), natomiast 3,4\% respondentów to rozwódki i rozwodnicy. Poniżej zaprezentowano wyniki badań własnych.

Tabela 1 przedstawia procentowy rozkład odpowiedzi respondentów na pytanie dotyczące subiektywnej opinii ankietowanych na temat pobierania narządów od zmarłych i przeszczepiania ich innym osobom.

Tabela 1. Opinia badanych na temat idei przeszczepiania narządów.

\begin{tabular}{|c|c|c|c|c|}
\hline \multirow{3}{*}{$\begin{array}{l}\text { Czy uważa Pan/Pani za } \\
\text { słuszne pobieranie narządów } \\
\text { od osób zmarłych i } \\
\text { przeszczepianie ich innym w } \\
\text { celu ratowania życia lub } \\
\text { przywracania zdrowia? }\end{array}$} & \multicolumn{4}{|c|}{ Odpowiedzi } \\
\hline & \multicolumn{2}{|c|}{$\begin{array}{ll}\text { PWSZ } & \text { we } \\
\text { Włocławku }\end{array}$} & \multicolumn{2}{|c|}{ CBOS } \\
\hline & $\%$ & $\mathbf{N}$ & $\%$ & $\mathbf{N}$ \\
\hline Zdecydowanie tak & $76,2 \%$ & 61 & $65 \%$ & 639 \\
\hline Raczej tak & $23,8 \%$ & 19 & $28 \%$ & 275 \\
\hline Raczej nie & - & - & $3 \%$ & 29 \\
\hline Zdecydowanie nie & - & - & $1 \%$ & 10 \\
\hline Trudno powiedzieć & - & - & $3 \%$ & 29 \\
\hline
\end{tabular}

Źródło: wynik badań własnych 
Wszyscy studenci uważają za słuszne pobieranie narządów od zmarłych i przeszczepianie ich innym osobom w celu ratowania życia. Zdecydowanie potwierdziło to $76,2 \%$ badanych a 23,8\% udzieliło odpowiedzi „raczej tak”. W badaniu CBOS po3\% respondentów raczej nie uważało tego za słuszne lub wskazywało odpowiedź „trudno powiedzieć”. Natomiast 1\% ankietowanych zdecydowanie nie popierało tej idei.

Tabela 2 przedstawia procentowy rozkład odpowiedzi respondentów na temat wyrażenia zgody na pośmiertne pobranie narządów do przeszczepów.

Tabela 2. Opinia respondentów na temat wyrażenia zgody na pobranie narządów po śmierci.

\begin{tabular}{|c|c|c|c|c|}
\hline \multirow{3}{*}{$\begin{array}{l}\text { Czy wyraziłby/wyraziłaby } \\
\text { Pan/Pani zgodę na to, aby po } \\
\text { śmierci pobrano od Pana/Pani }\end{array}$} & \multirow{2}{*}{\multicolumn{4}{|c|}{ Odpowiedzi }} \\
\hline & & & & \\
\hline & \multirow{2}{*}{\multicolumn{2}{|c|}{$\begin{array}{ll}\text { PWSZ we } \\
\text { Włocławku }\end{array}$}} & \multirow{2}{*}{\multicolumn{2}{|c|}{ CBOS }} \\
\hline $\begin{array}{lll}\text { narządy } & w & \text { celu }\end{array}$ & & & & \\
\hline $\begin{array}{l}\text { przeszczepienia ich innym } \\
\text { osobom? }\end{array}$ & $\%$ & $\mathbf{N}$ & $\%$ & $\mathbf{N}$ \\
\hline Zdecydowanie tak & $60 \%$ & 48 & $52 \%$ & 511 \\
\hline Raczej tak & $28,7 \%$ & 23 & $28 \%$ & 275 \\
\hline Raczej nie & $10 \%$ & 8 & $7 \%$ & 69 \\
\hline Zdecydowanie nie & $1,3 \%$ & 1 & $4 \%$ & 39 \\
\hline Trudno powiedzieć & & - & $9 \%$ & 88 \\
\hline
\end{tabular}

Źródło: wynik badań własnych

$\mathrm{Z}$ tabeli 2 wynika, iż większość studentów (60\%) zdecydowanie wyraziłoby zgodę na to, aby po śmierci pobrać od nich narządy do transplantacji a $28,7 \%$ badanych wskazało, że raczej zgodziłoby się na taka procedurę. Tylko 1 osoba $(1,3 \%)$ była temu zdecydowanie przeciwna a $10 \%$ respondentów wskazało odpowiedź „raczej nie”. Ponad połowa ankietowanych $\mathrm{z}$ badania CBOS (52\%) zdecydowanie wyraziłaby zgodę na transplantację 
a $28 \%$ badanych raczej podjęłoby taką decyzję. Sprzeciwiłoby się temu stanowczo $4 \%$ respondentów a $7 \%$ ankietowanych raczej nie zgodziłoby się na taką procedurę.

Tabela 3 obrazuje procentowy rozkład odpowiedzi badanych na temat rozmowy $\mathrm{z}$ członkami rodziny na temat przekazania narządów po śmierci do transplantacji.

Tabela 3. Odpowiedzi badanych nt. rozmowy $z$ bliskimi o przekazaniu narządów po śmierci do transplantacji.

\begin{tabular}{|c|c|c|c|c|}
\hline \multirow{3}{*}{$\begin{array}{l}\text { Czy rozmawiał/rozmawiała } \\
\text { Pan/Pani ze swoimi członkami } \\
\text { rodziny na temat przekazania } \\
\text { Pana/Pani narządów po śmierci, } \\
\text { aby przeszczepić je osobom } \\
\text { czekającym na transplantację? }\end{array}$} & \multicolumn{4}{|c|}{ Odpowiedzi } \\
\hline & \multicolumn{2}{|c|}{$\begin{array}{l}\text { PWSZ we } \\
\text { Włocławku }\end{array}$} & \multicolumn{2}{|c|}{ CBOS } \\
\hline & $\%$ & $\mathbf{N}$ & $\%$ & $\mathbf{N}$ \\
\hline Tak, rozmawiałem/rozmawiałam & $70 \%$ & 56 & $25 \%$ & 246 \\
\hline $\begin{array}{ll}\text { Nie, } & \text { nie } \\
\text { rozmawiałem/rozmawiałam } & \end{array}$ & $30 \%$ & 24 & $75 \%$ & 737 \\
\hline
\end{tabular}

Źródło: wynik badań własnych

Zdecydowana większość studentów (70\%) potwierdziło, że rozmawiało z członkami swojej rodziny na temat przekazania narządów po śmierci. Nie uczyniło tego $30 \%$ badanych. Natomiast w badaniu CBOS zaledwie $25 \%$ badanych podjęło taką rozmowę ze swoimi bliskimi a większość respondentów (75\%) nie rozmawiało na ten temat.

W tabeli 4 przedstawiono procentowy rozkład odpowiedzi dotyczący oświadczenia woli, które pozwala potwierdzić zgodę na pobranie narządów w sytuacji śmierci. 
Tabela 4. Odpowiedzi badanych na temat oświadczenia woli.

\begin{tabular}{|c|c|c|c|c|}
\hline \multirow{3}{*}{$\begin{array}{l}\text { Czy słyszał/słyszała Pan/Pani } \\
\text { o oświadczeniu woli, które } \\
\text { pozwala w krytycznej sytuacji } \\
\text { potwierdzić Pana/Pani zgodę } \\
\text { na pobranie narządów? }\end{array}$} & \multicolumn{4}{|c|}{ Odpowiedzi } \\
\hline & \multicolumn{2}{|c|}{$\begin{array}{ll}\text { PWSZ we } \\
\text { Włocławku }\end{array}$} & \multicolumn{2}{|c|}{ CBOS } \\
\hline & $\%$ & $\mathbf{N}$ & $\%$ & $\mathbf{N}$ \\
\hline Tak, słyszałem/słyszałam & $97,5 \%$ & 78 & $62 \%$ & 609 \\
\hline Nie, nie słyszałem/słyszałam & $2,5 \%$ & 2 & $37 \%$ & 364 \\
\hline Trudno powiedzieć & - & - & $1 \%$ & 10 \\
\hline
\end{tabular}

Źródło: wynik badań własnych

Tylko 2,5\% studentów nie słyszało o oświadczeniu woli, a z badania CBOS wynika, że sytuacja taka dotyczyło $37 \%$ respondentów. Natomiast $1 \%$ ankietowanych nie potrafiło jednoznacznie udzielić odpowiedzi na to pytanie.

W tabeli 5ukazano odpowiedzi respondentów dotyczące gotowości podpisania oświadczenia woli.

Tabela 5. Opinia badanych dotycząca udzielenia zgody na podpisanie oświadczenia woli.

\begin{tabular}{|l|l|l|l|l|}
\hline $\begin{array}{l}\text { Czy byłby/byłaby Pan/Pani } \\
\text { gotowa podpisać oświadczenie } \\
\text { woli? }\end{array}$ & \multicolumn{4}{|l|}{ Odpowiedzi } \\
\cline { 2 - 5 } & $\begin{array}{l}\text { OWSZ we } \\
\text { Włocławku }\end{array}$ & \multicolumn{2}{l|}{ CBOS } \\
\cline { 2 - 5 } & $\%$ & N & $\%$ & N \\
\hline Zdecydowanie tak & $36,3 \%$ & 29 & $38 \%$ & 374 \\
\hline Raczej tak & $36,3 \%$ & 29 & $32 \%$ & 315 \\
\hline Raczej nie & $10 \%$ & 8 & $10 \%$ & 98 \\
\hline Zdecydowanie nie & $1,2 \%$ & 1 & $4 \%$ & 39 \\
\hline Trudno powiedzieć & - & - & $13 \%$ & 128 \\
\hline $\begin{array}{l}\text { Już podpisałem/podpisałam takie } \\
\text { oświadczenie }\end{array}$ & $16,2 \%$ & 13 & $3 \%$ & 29 \\
\hline
\end{tabular}

Źródło: wynik badań własnych 
Większość studentów zadeklarowała gotowość podpisania oświadczenia woli. Potwierdziło to zdecydowanie $36,3 \%$ ankietowanych a kolejnych $36,3 \%$ respondentów było raczej zdecydowanych. Podjęło takie działanie 16,2\% studentów. Natomiast $10 \%$ osób wskazało, że raczej tego nie uczyni a 1 osoba podała, że zdecydowanie nie jest gotowa podjąć takiego działania. $\mathrm{W}$ badaniu CBOS zupełnie zdecydowanych podpisać takie oświadczenie było $38 \%$ respondentów a 32\% raczej potwierdziło taką postawę. Tylko $3 \%$ ankietowanych wskazało, że podpisało już taki dokument. Raczej nie było przygotowanym na takie oświadczenie $10 \%$ badanych a 13\% nie potrafiło udzielić odpowiedzi na powyższe pytanie. Zdecydowanie przeciwnym udzieleniu zgody było $4 \%$ ankietowanych.

W tabeli 6 zaprezentowano procentowy rozkład odpowiedzi dotyczący wyrażenia zgody na pobranie narządów po śmierci od bliskiej osoby w momencie, gdyby osoba ta za życia nie wyraziła sprzeciwu.

Tabela 6. Opinia badanych na temat wyrażenia zgody na pobranie od bliskiej osoby narządów do transplantacji po jej śmierci.

\begin{tabular}{|c|c|c|c|c|}
\hline \multirow{3}{*}{$\begin{array}{l}\text { Czy w momencie śmierci } \\
\text { bliskiej } \\
\text { wyraziłby/wyraziłaby } \\
\text { Pan/Pani zgodę na pobranie od } \\
\text { niej narządów, aby ratować } \\
\text { życie innej osobie, w sytuacji, } \\
\text { gdy osoba ta nie miała nic } \\
\text { przeciwko pobraniu od niej } \\
\text { narządów? }\end{array}$} & \multicolumn{4}{|c|}{ Odpowiedzi } \\
\hline & \multicolumn{2}{|c|}{$\begin{array}{l}\text { PWSZ we } \\
\text { Włocławku }\end{array}$} & \multicolumn{2}{|c|}{ CBOS } \\
\hline & $\%$ & $\mathbf{N}$ & $\%$ & $\mathbf{N}$ \\
\hline $\begin{array}{ll}\text { Nie } & \text { wyraziłbym/wyraziłabym } \\
\text { zgody } & \end{array}$ & $2,5 \%$ & 2 & $3 \%$ & 29 \\
\hline Wyraziłbym/wyraziłabym zgodę & $77,5 \%$ & 62 & $89 \%$ & 875 \\
\hline Trudno powiedzieć & $20 \%$ & 16 & $8 \%$ & 79 \\
\hline
\end{tabular}

Źródło: wynik badań własnych 
Z tabeli 6 wynika, że większość studentów i respondentów badania CBOS wyraziłaby zgodę na pobranie narządów po śmierci bliskiej osoby w sytuacji, gdy nie wyraziła ona sprzeciwu za życia. Taką odpowiedź wybrało 77,5\% studentów oraz $89 \%$ ankietowanych CBOS-u. Tylko 2,5\% studentów i 3\% ankietowanych z Polski udzieliło odpowiedzi negatywnej. Natomiast 20\% respondentów z PWSZ we Włocławku i 8\% badanych z Polski nie potrafiło udzielić jednoznacznej odpowiedzi na to pytanie.

W tabeli 7 został przedstawiony procentowy rozkład odpowiedzi dotyczący wyrażenia zgody na pobranie narządów od bliskiej osoby w sytuacji, gdy osoba ta nie wypowiedziałaby się na ten temat i nie wiadomo, jakie miała zdanie.

Tabela 7. Opinia badanych na temat pobrania narządów od bliskiej osoby do transplantacji po jej śmierci w sytuacji, gdy nie wiadomo jakie przyjęła stanowisko $w$ tym zakresie za życia.

\begin{tabular}{|c|c|c|c|c|}
\hline \multirow{3}{*}{$\begin{array}{l}\text { Czy w momencie śmierci } \\
\text { bliskiej } \\
\text { wyraziłby/wyraziłaby } \\
\text { Pan/Pani zgodę na pobranie od } \\
\text { niej narządów, aby ratować } \\
\text { życie innej osobie, w sytuacji, } \\
\text { gdy osoba ta nie wypowiadała } \\
\text { się na ten temat i nie wiadomo, } \\
\text { jakie miała zdanie na ten } \\
\text { temat? }\end{array}$} & \multicolumn{4}{|c|}{ Odpowiedzi } \\
\hline & \multicolumn{2}{|c|}{$\begin{array}{l}\text { PWSZ we } \\
\text { Włocławku }\end{array}$} & \multicolumn{2}{|c|}{ CBOS } \\
\hline & $\%$ & $\mathbf{N}$ & $\%$ & $\mathbf{N}$ \\
\hline $\begin{array}{ll}\text { Nie } & \text { wyraziłbym/wyraziłabym } \\
\text { zgody } & \end{array}$ & $23,8 \%$ & 19 & $14 \%$ & 138 \\
\hline Wyraziłbym/wyraziłabym zgodę & $37,5 \%$ & 30 & $69 \%$ & 678 \\
\hline Trudno powiedzieć & $38,7 \%$ & 31 & $17 \%$ & 167 \\
\hline
\end{tabular}

Źródło: wynik badań własnych 
Większość studentów (38,7\%) nie udzieliła jednoznacznej odpowiedzi na to, czy wyraziłaby zgodę na transplantację narządu od bliskiej osoby po jej śmierci, nie znając jej stanowiska za życia w tym zakresie. Zgody udzieliłoby $37,5 \%$ badanych. Natomiast przeciwnych takiemu działaniu było 23,8\% studentów. Większość respondentów CBOS (69\%) była zdania, że wyraziłaby zgodę na transplantację narządów bliskiej osoby pomimo, że nie znała jej stanowiska za życia w tym temacie. Przeciwnych takiemu działaniu było $14 \%$ badanych, a $17 \%$ osób nie udzieliła jednoznacznej odpowiedzi.

Tabela 8 prezentuje procentowy rozkład odpowiedzi na temat wyrażenia zgody na pobranie narządów od bliskiej osoby w momencie wyrażenia przez nią sprzeciwu za jej życia.

Tabela 8. Opinia respondentów na temat pobrania narządów od bliskiej osoby w sytuacji, gdy osoba ta była przeciwna oddaniu narządów.

\begin{tabular}{|l|l|l|l|l|}
\hline $\begin{array}{l}\text { Czy w momencie śmierci } \\
\text { bliskiej osoby }\end{array}$ & \multicolumn{4}{|l|}{ Odpowiedzi } \\
\cline { 2 - 5 } $\begin{array}{l}\text { wyraziłby/wyraziłaby } \\
\text { Pan/Pani zgodę na pobranie od } \\
\text { niej narządów, aby ratować }\end{array}$ & $\begin{array}{l}\text { PWSZ we } \\
\text { Włocławku }\end{array}$ & CBOS \\
\cline { 2 - 5 } $\begin{array}{l}\text { życie innej osobie, w sytuacji, } \\
\text { gdy osoba ta była przeciwna } \\
\text { oddaniu narządów? }\end{array}$ & & $\mathbf{N}$ & $\%$ & $\mathbf{N}$ \\
\hline $\begin{array}{l}\text { Nie wyraziłbym/wyraziłabym } \\
\text { zgody }\end{array}$ & $67,5 \%$ & 54 & $67 \%$ & 659 \\
\hline Wyraziłbym/wyraziłabym zgodę & $13,7 \%$ & 11 & $22 \%$ & 216 \\
\hline Trudno powiedzieć & $18,8 \%$ & 15 & $11 \%$ & 108 \\
\hline
\end{tabular}

Źródło: wynik badań własnych

Z tabeli 8 wynika, że większość badanych nie wyraziłaby zgody na pobranie narządów od bliskiej osoby w sytuacji, gdy osoba 
ta za życia była przeciwna transplantacji. Takiej odpowiedzi udzieliło $67,5 \%$ studentów oraz $67 \%$ ankietowanych z badania CBOS-u. Zgody na transplantację udzieliłoby $13,7 \%$ respondentów z PWSZ we Włocławku oraz 22\% badanych z Polski. Udzielić jednoznacznej odpowiedzi na to pytanie nie potrafiło $18,8 \%$ studentów oraz $11 \%$ ankietowanych Polaków.

Tabela 9 przedstawia procentowy rozkład odpowiedzi dotyczący momentu, w którym u człowieka następuje śmierć.

Tabela 9. Opinia badanych na temat momentu, w którym dochodzi do śmierci człowieka.

\begin{tabular}{|c|c|c|c|c|}
\hline \multirow{3}{*}{$\begin{array}{lr}\text { W którym } & \text { momencie } \\
\text { Pana/Pani } & \text { zdaniem } \\
\text { następuje śmierć człowieka? }\end{array}$} & \multicolumn{4}{|c|}{ Odpowiedzi } \\
\hline & \multicolumn{2}{|c|}{$\begin{array}{ll}\text { PWSZ we } & \text { włocławku } \\
\text { Wło }\end{array}$} & \multicolumn{2}{|c|}{ CBOS } \\
\hline & $\%$ & $\mathbf{N}$ & $\%$ & $\mathbf{N}$ \\
\hline $\begin{array}{l}\text { W momencie zatrzymania } \\
\text { pracy serca }\end{array}$ & $36,3 \%$ & 29 & $40 \%$ & 393 \\
\hline $\begin{array}{l}\text { W momencie nieodwracalnego } \\
\text { zniszczenia mózgu }\end{array}$ & $60 \%$ & 48 & $49 \%$ & 482 \\
\hline Nie wiem & $3,7 \%$ & 3 & $11 \%$ & 108 \\
\hline
\end{tabular}

Źródło: wynik badań własnych

Z tabeli 9 wynika, że większość respondentów za moment śmierci uznało nieodwracalne zniszczenie mózgu. Takiej odpowiedzi udzieliło $60 \%$ studentów i $49 \%$ ankietowanych $\quad \mathrm{z}$ badania CBOS.Zatrzymanie pracy serca jako moment śmierci człowieka wskazało 36,3\%respondentów z PWSZ we Włocławku oraz $40 \%$ badanych

z Polski. Nie potrafiło udzielić odpowiedzi na to pytanie 3,7\% studentów i 11\% osób uczestniczących w badaniu CBOS. 
Tabela 10 ukazuje procentowy rozkład odpowiedzi respondentów na temat optymalnych regulacji prawnych dotyczących pobierania narząadów do transplantacji.

Tabela 10. Opinia badanych na temat optymalnych regulacji dotyczących pobierania narządów do transplantacji.

\begin{tabular}{|c|c|c|c|c|}
\hline \multirow{3}{*}{\begin{tabular}{lr} 
Na świecie & istnieje wiele \\
regulacji & \multicolumn{2}{c}{ dotyczących } \\
pobierania narządów do \\
przeszczepów. Który z z \\
wymienionych sposobów \\
uważa Pan/Pani za lepszy:
\end{tabular}} & \multicolumn{4}{|c|}{ Odpowiedzi } \\
\hline & \multicolumn{2}{|c|}{$\begin{array}{ll}\text { PWSZ } & \text { we } \\
\text { Włocławku } & \end{array}$} & \multicolumn{2}{|c|}{ CBOS } \\
\hline & $\%$ & $\mathbf{N}$ & $\%$ & $\mathbf{N}$ \\
\hline $\begin{array}{l}\text { Ten, w którym narządy można } \\
\text { pobrać tylko od osób, które za } \\
\text { życia wyraziły na to zgodę } \\
\text { podpisując } \\
\text { dokument }\end{array}$ & $56,3 \%$ & 45 & $43 \%$ & 423 \\
\hline $\begin{array}{l}\text { Ten, w którym narządy można } \\
\text { pobrać od wszystkich, którzy } \\
\text { nie wyrazili sprzeciwu za życia }\end{array}$ & $30 \%$ & 24 & $42 \%$ & 413 \\
\hline Żaden nie jest dobry & $2,5 \%$ & 2 & $5 \%$ & 49 \\
\hline Trudno powiedzieć & $11,2 \%$ & 9 & $10 \%$ & 98 \\
\hline
\end{tabular}

Źródło: wynik badań własnych

Regulacje dotyczące pobierania narządów do transplantacji tylko od osób, które za życia wyraziły na to zgodę podpisując odpowiedni dokument, wskazała większość studentów (56,3\%) oraz ankietowanych z badania CBOS (43\%). Pobranie narządów od osób, które nie wyraziły sprzeciwu za życia wskazało $30 \%$ badanych z PWSZ we Włocławku oraz 42\% respondentów z Polski. Żadnej z wymienionych regulacji nie wybrało $2,5 \%$ studentów oraz $5 \%$ badanych Polaków. Jednoznacznej odpowiedzi na to pytanie 
nie potrafiło udzielić 11,2\% ankietowanych osób z PWSZ oraz 10\% respondentów z badania CBOS.

Tabela 11 obrazuje procentowy rozkład odpowiedzi respondentów dotyczący przepisów obowiązujących w Polsce związanych z pobieraniem narządów do transplantacji.

Tabela 11. Opinia badanych na temat przepisów regulujących transplantację narządów w Polsce.

\begin{tabular}{|l|l|l|l|l|}
\hline $\begin{array}{l}\text { Jakie przepisy według } \\
\text { Pana/Pani wiedzy dotyczące } \\
\text { pobierania narządów } \\
\text { obowiązują w Polsce? }\end{array}$ & \multicolumn{4}{|l|}{ Odpowiedzi } \\
\cline { 2 - 5 } & $\begin{array}{l}\text { PWSZ włocławku } \\
\text { Wła }\end{array}$ & \multicolumn{2}{|l|}{ CBOS } \\
\cline { 2 - 6 } & $\%$ & N & $\%$ & N \\
\hline $\begin{array}{l}\text { Nie orientuję się, jakie w } \\
\text { Polsce obowiązują przepisy }\end{array}$ & $31,2 \%$ & 25 & $46 \%$ & 452 \\
\hline $\begin{array}{l}\text { Konieczne jest wyrażenie } \\
\text { zgody za życia }\end{array}$ & $12,5 \%$ & 10 & $29 \%$ & 285 \\
\hline $\begin{array}{l}\text { Wystarczy nie wyrażenie } \\
\text { sprzeciwu za życia }\end{array}$ & $56,3 \%$ & 45 & $20 \%$ & 197 \\
\hline Trudno powiedzieć & - & - & $5 \%$ & 49 \\
\hline
\end{tabular}

Źródło: wynik badań własnych

Z tabeli 11 wynika, że 31,2\% studentów oraz 46\% Polaków z badania CBOS nie orientowało się, jakie przepisy dotyczące transplantacji narządów obowiązują w naszym kraju. Ponad połowa respondentów z uczelni $(56,3 \%)$ oraz $20 \%$ ankietowanych Polaków wskazała, że wystarczy nie wyrażenie sprzeciwu za życia. Natomiast konieczność wyrażenia takiej zgody za życia podkreśliło 12,5\% studentów i 29\% osób z badania CBOS. Nie udzieliło jednoznacznej odpowiedzi w tym zakresie 5\% respondentów ankiety CBOS. 


\section{Dyskusja}

Medycyna transplantacyjna w Polsce zaczęła rozwijać się od 1966r. Właśnie wtedy, w Warszawie dokonano pierwszego udanego przeszczepu nerki[5]. Szacuje się, iż co 5 dni w Polsce umiera pacjent, który oczekuje na transplantację narządu. Dzięki poprawie skuteczności procedur i regulacji prawnych, dotyczących przeprowadzanych transplantacji narządów i tkanek, powyższa metoda terapii staje się uznanym rozwiązaniem w leczeniu pacjentów w przebiegu schyłkowej niewydolności narządów [1,2]. Traktowana jest jako metoda ratowania życia

Idea transplantacji bywa nadal przedmiotem licznych dyskusji. Wyniki wielu badań, w tym także prowadzonych wśród studentów, wskazują, że jest akceptowana jako metoda terapeutyczna w sytuacji pobrania narządu od zmarłej osoby. Największe obawy dotyczą definicji śmierci mózgowej $[9,10,11]$.

W licznych badaniach, w tym badaniach własnych, czy przeprowadzonych przez Centrum Badania Opinii Społecznej zdecydowana większość respondentów uważa ideę pobierania narządów do transplantacji za słuszną [4,9,10,11]. Wśród studentów Państwowej Wyższej Szkoły Zawodowej we Włocławku żadna $\mathrm{z}$ ankietowanych osób nie wyraziła dezaprobaty. Blisko 90\% respondentów z Włocławka oraz około $80 \%$ badanych Polaków zgodziłaby się, aby po śmierci pobrano od niego narządy w celu przeszczepienia ich innym osobom [4].

Znaczące różnice uwidaczniają się $\mathrm{w}$ pytaniu dotyczącym rozmowy $\mathrm{z}$ członkami rodziny na temat przekazania narządów po śmierci osobom czekającym na transplantację. Większość respondentów z PWSZ we Włocławku (70\%) deklaruje, że podjęła taką rozmowę ze swoimi najbliższymi. Z kolei rozmowy na ten temat nie zrealizowało $75 \%$ ankietowanych uczestniczących $\mathrm{w}$ badaniu CBOS [4]. 
Jak wynika z badań własnych, badań CBOS i innych autorów znaczna część polskiego społeczeństwa osób pomimo działań promujących nadal nie wie czym jest, bądź nie byłaby gotowa podpisać oświadczenia woli. Jest to dokument mający na celu stwierdzenie woli wyrażonej za życia a dotyczącej donacji tak, aby ułatwić decyzje rodzinie, lekarzom [3,10]. W badaniach własnych 2,5\% studentów wskazało, że nie słyszało o takim oświadczeniu, a 11,2\% nie byłaby gotowa podpisać takiego dokumentu. Spośród respondentów CBOS prawie 40\% osób nie wiedziało, czym jest oświadczenie woli, a 27\% Polaków nie zdecydowałaby się na jego podpisanie [4]. Badania wskazują, że nie zawsze deklaracje dotyczące zgody na transplantację narządów korespondują ze złożeniem oświadczenia woli $[9,10]$.

Istotnym tematem poruszonym $\mathrm{w}$ aktualnych badaniach był moment śmierci człowieka. Respondenci mieli odpowiedzieć, kiedy ich zdaniem do niego dochodzi. Jedną z wymienionych odpowiedzi było stwierdzenie nieodwracalnych uszkodzeń mózgu. Przez dziesiątki lat rozpoznanie zgonu opierało się na nieodwracalnym ustaniu krążenia i czynności oddechowej. Współcześnie pomimo braku akcji oddechowej po przywróceniu krążenia, jest możliwe podtrzymywanie funkcji innych narządów takich jak nerki czy wątroba. Żadna forma terapii nie jest jednak skuteczna w sytuacji, gdy dochodzi do nieodwracalnego uszkodzenia mózgu. Śmierć mózgu jest jednoznaczna ze śmiercią człowieka $[12,13]$. Taką odpowiedź wybierało $60 \%$ respondentów PWSZ we Włocławku oraz 49\% badanych przez CBOS. Przeszło jedna trzecia badanych studentów oraz Polaków uznała, iż człowiek umiera w momencie zatrzymania pracy serca [4]. Podobne kontrowersje co do momentu określenia śmierci człowieka potwierdzają także inne badania $[9,11]$.

Aspekt przepisów regulujących pobieranie narządów w Polsce ukazuje podział opinii i różnice $\mathrm{w}$ wiedzy wśród respondentów biorących udział w aktualnym badaniu. Ponad 56\% studentów wskazała, iż optymalną regulacją jest ta, wg której narządy można 
pobrać tylko od osób, które za życia wyraziły na to zgodę, podpisując odpowiedni dokument. Tego samego zdania było 43\% respondentów badania CBOS. Niestety ponad $31 \%$ studentów oraz $46 \%$ ankietowanych przez CBOS nie orientuje się, jakie w Polsce obowiązują przepisy w tym zakresie [4]. Potwierdzają ten fakt także wyniki innych polskich badań $[9,10]$.

\section{Wnioski}

Stosunek studentów PWSZ we Włocławku jak i zdecydowanej większości Polaków wobec pobierania i transplantacji narządów jest pozytywny. Istnieje potrzeba propagowania idei transplantologii oraz wiedzy na temat zasad pobierania i przeszczepiania narządów i tkanek.

\section{Zalecenia dla praktyki pielęgniarskiej}

Propagowanie idei pobierania i transplantacji narządów to zadanie, w którym aktywny udział powinny brać pielęgniarki, jako członkowie interdyscyplinarnego zespołu terapeutycznego.

\section{Bibliografia / Bibliography:}

1. Czerwiński J., Małkowski P. Medycyna transplantacyjna dla pielęgniarek. Wydawnictwo Lekarskie PZWL, Warszawa 2017.

2. Kołodyński P., Drab P. Prawne regulacje pobierania i transplantacji narządów oraz tkanek $\mathrm{w}$ ujęciu europejskiej konwencji bioetycznej. Przegląd Europejski. 2016; 1(39): 52-65.

3. Centrum Organizacyjno-Koordynacyjne do Spraw Transplantacji „Poltransplant”. $\quad$ RetrievedJune 19, 2019, fromhttps://www.poltransplant.org.pl/. 
4. Centrum Badania Opinii Społecznej. Postawy wobec transplantacji narządów. Komunikat z badań nr 119/2016. Warszawa 2016r.RetrievedJune 19, 2019, from https://www.cbos.pl/SPISKOM.POL/2016/K_119_16.PDF.

5. Sieradza A. Tajemnice transplantacji. Wyd. Nauk. PWN, Warszawa 2017.

6. Romanowska U, Lizak D, Jaśkiewicz J i wsp. Dawstwo i transplantacja narządów w opinii studentów pielęgniarstwa studiów uzupełniających pomostowych. Pielęg XXI w 2012; 4(41): 123-128.

7. Użdżalewicz Z, Mess E. Czynniki wpływające na stan wiedzy społeczeństwa na temat transplantacji narządów. Probl Pieleg 2016; 24(34): 232-237.

8. Wojczyk A. Stan wiedzy studentów opolskich uczelni wyższych na temat transplantacji narządów. Puls Uczelni 2013; 7(4): 34-38.

9. Juszczak K. i wsp.Analiza postaw i czynników wpływających na podjęcie decyzji o transplantacji narządów wśród społeczności wiejskiej.

PielęgniarstwoChirurgiczneiAngiologiczne.2016;3:141-145.Retrieved June 19, 2019, from

file://C:/Users/ThinkPad/AppData/Local/Temp/PCIA_Art_28562-10-

1.pdf.

10. Mazur A i wsp. Zachowania studentów dotyczące przeszczepiania narządów z uwzględnieniem czynnikówsocjodemograficznych. Hygeia Public Health 2018, 53(4): 371-376.

11. Lisowska D. i wsp. Wybrane zagadnienia związane $\mathrm{z}$ transplantacją w opinii studentów z uwzględnieniem czynników socjodemograficznych. MedOg Nauk Zdr. 2018; 24(1):65-69. Retrieved June 19, 2019, fromhttp://www.monz.pl/Wybrane-zagadnienia-zwiazane-ztransplantacja-w-opinii-studentow-z-uwzglednieniem,86585,0,1.html.

12. Rowiński W. Kiedy umiera człowiek? Kardiochirurgia i Torakochirurgia Polska. 2012; 2: 157-158. 
13. Kubik T. Czym jest śmierć mózgu? Gabinet Prywatny.2008; 2: 27-31.

Otrzymano: 12.05.2019r.

Zaakceptowano: 01.06.2019r. 